\title{
Epidemiologic, clinical, diagnostic and therapeutic aspects of visceral leishmaniasis in renal transplant recipients: experience from thirty cases
}

Avelar Alves de Silva ${ }^{1,2^{*}}$, Álvaro Pacheco E Silva Filho ${ }^{3,4}$, Ricardio de Castro Cinta Sesso ${ }^{3}$, Ronaldo de Matos Esmeraldo ${ }^{5}$, Cláudia Maria Costa de Oliveira ${ }^{6}$, Paula Frassinetti Castelo Branco Camurca Fernandes ${ }^{6}$, Rodrigo Alves de Oliveira $^{7}$, Leila Silveira Veira de Silva ${ }^{7}$, Valencio Pereira de Carvalho ${ }^{7}$, Carlos Henrique Nery Costa ${ }^{8}$, Jesusmar Ximenes Andrade ${ }^{9}$, Diana Marisa Barros da Silva ${ }^{2}$ and Roosevelt Valente Chaves ${ }^{2}$

\begin{abstract}
Background: Visceral leishmaniasis is a disease caused by the protozoan Leishmania sp. and is transmitted by Lutzomyia longipalpis (sand fly). In renal transplant recipients, visceral leishmaniasis causes severe damage to the liver, spleen, and hematopoietic system, as well as poor outcomes for patients with transplanted kidneys. This study describes the largest series of cases of visceral leishmaniasis in renal transplant recipients, providing important information about the diagnostic routines and therapeutic strategies in this patient population.

Methods: A retrospective, descriptive study was performed to analyze the distribution and evaluate the extent of the epidemiologic, clinical, diagnostic and therapeutic aspects of 30 renal transplant recipients from endemic regions who presented with visceral leishmaniasis in the post-transplantation period.
\end{abstract}

Results: In this study, visceral leishmaniasis was more frequent in men (80\%). The mean age of presentation was $40 \pm 10.5$ years. The majority of patients worked in urban areas (66.7\%), cohabitated with domestic animals (90\%), and were from low-income households. In $73.3 \%$ of cases, diagnosis was made by direct isolation of Leishmania forms. Patients were treated with liposomal amphotericin, resulting in a high degree of disease remission (80\%).

Conclusions: This study describes the largest series of visceral leishmaniasis in renal transplant recipients and expands clinical-epidemiological knowledge for transplantation teams to perform adequate disease management for this specific patient population.

Keywords: Visceral leishmaniasis, Renal transplant recipients, Infection after transplant

\section{Background}

Visceral leishmaniasis (VL) is an opportunistic disease caused by a protozoan of the genus Leishmania [1,2]. The disease is endemic to all continents; specialists consider it a neglected disease, as there are more than 5 million cases annually and the disease has a high incidence among the low socioeconomic, immunosuppressed, and malnourished population [2,3]. In Brazil, the incidence of VL is 2 cases per 100,000 inhabitants and in the states of Piauí and Maranhão, located in the

\footnotetext{
* Correspondence: avelaralvesdasilva@gmail.com

'General Clinic Department, Federal University of Piauí, Piauí, Brazil

${ }^{2}$ Renal Transplant Unit, Hospital Alianca Casamater, Piaú, Brazil

Full list of author information is available at the end of the article
}

Northeast of Brazil, incidence rises to 4 cases per 100,000 inhabitants [4]. Over the past decade, the mean annual cases in Brazil were 3,156, with $66 \%$ of all cases occurring in the Northeast and $48 \%$ in the states of Piauí and Ceará [4]. Of note, less than 100 cases of VL after kidney transplantation have been reported previously [5]. Brazil performs 8,000 kidney transplants per year; however, VL is a rare endemic disease and there is no national data of its incidence and prevalence in renal transplant recipients. Several studies have shown that in endemic areas transplant recipients might contract leishmania during transplantation, which might remain asymptomatic for a long period or for life. One cause of this is that serology for leishmaniasis is not yet

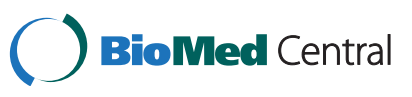


a part of the pre-transplant evaluation protocol in many transplant centers [6,7]. VL is more common in children (54.4\%) and in males (60\%), and it is common in areas with a dry climate, an annual rainfall less than $800 \mathrm{~mm}$, and a physiographic environment composed of valleys and mountains. However, the VL incidence has increased in urban areas, especially in the peripheries of large urban centers [8]. In recent years, kidney transplantation, particularly renal replacement therapy, has been initiated in poor regions and is associated with the standardization of surgical techniques and the ease of access to immunosuppressors [9-11]. Thus, problems due to acute rejection and surgical complications have decreased in these regions. Meanwhile, endemic and opportunistic infections such as VL have become the major preoccupation of transplantation teams, because these infections are directly associated with both graft dysfunction and the survival of renal transplant recipients [12].

There are currently no clinical protocols for the diagnosis or treatment of VL-infected renal transplant recipients, and few studies have focused on the epidemiology and risk factors associated with the disease in this specific patient population [12,13]. This study of 30 cases constitutes the largest series of this patient population reported and aims to highlight the epidemiologic, clinical, diagnostic and therapeutic aspects of VL in renal transplant recipients, as well as contribute to the establishment of better practices in the clinical management of these patients, with the possibility of improving patient survival and reducing graft rejection.

\section{Methods}

\section{Study sample and location}

Thirty kidney recipients were studied between January 1989 and January 2013. Patients resided and were followed-up postoperatively in transplant centers in regions where VL is endemic. The study location was the states of Piauí and Ceará, which are located in the Southern Hemisphere in Northeastern Brazil [14].

\section{Study design}

This was a descriptive, retrospective study showing the relative distribution of renal transplant recipients with post-transplant VL, focusing on epidemiologic, clinical, diagnostic and therapeutic aspects.

\section{Patient inclusion and exclusion criteria}

All confirmed VL cases who met the inclusion criteria and agreed to participate were included. Two patients did not agree to participate in the study and were therefore excluded. Deceased patients were included or excluded following telephone contact and/or a domestic visit to direct family members or spouses, which included an invitation, explanation of the methodology and importance of the research, and agreement. There were 10 deceased patients at the time of data collection; only two were excluded, as their family members could not be located following a change in address. The study was initiated after informed consent of patients and family, and approval by the research ethics committee of the Hospital Geral de Fortaleza (HGF) and Casamater hospitals as well as the federal universities of Piauí and Ceará.

\section{Case definition}

Patients $(n=30)$ had chronic renal disease and were undergoing dialysis or conservative treatment. Kidney transplantation occurred between January 1989 and January 2013, and VL was detected post-transplantation. The patients were transplanted in the kidney transplant units of the Hospital Geral de Fortaleza (HGF), Hospital Universitário Walter Cantídio (HUWC), Hospital Universitário de Barbalha of the Universidade Federal do Ceará, and Hospital Aliança Casamater, which are all located in the states of Ceará and Piauí in Northeastern Brazil.

\section{VL treatment}

VL patients were treated with liposomal amphotericin at $4 \mathrm{mg} / \mathrm{kg} /$ day for 10 days, amphotericin B up to the maximum dose of $1 \mathrm{~g}$, or $N$-methylglucamine at $30 \mathrm{mg} / \mathrm{kg} /$ day for 20 days $[15,16]$.

\section{Clinical remission}

VL patients with no symptoms, signs, or laboratorial alterations 6 months post-treatment were considered cured $[17,18]$.

\section{Definition of relapse}

Relapse was defined as the occurrence of clinical manifestations of VL and new laboratorial identification of Leishmania in cases previously treated and considered cured up to 6 months post-treatment [19].

\section{Graft dysfunction}

Graft dysfunction was defined as an increase in serum creatinine $30 \%$ above the baseline values in biochemical analyses performed before VL treatment in the absence of other factors associated with acute kidney injury [20].

\section{Variables analyzed}

The following variables were analyzed. General characteristics included age, sex, ethnicity, breeding of or cohabitation with domestic animals, and ornamental and/ or fruit plant breeding grown indoors or outdoors. In this study, the cohabitation of patients with domestic animals was defined as patients raising and/or taking care of animals, as well as animal presence in the neighborhood 
of residence or workplace. Other variables included the existence or absence of paved roads, wastelands, regular waste collection, sewage, and electricity in the neighborhood of residence or at the workplace as well as rural or urban areas. Epidemiologic characteristics included education level, family income, type of housing, and awareness of human or canine VL. Clinical profile characteristics included the type of dialysis before transplant, posttransplantation blood transfusions, donor type, first transplantation or re-transplantation, immunosuppression protocol, bacterial and viral infections, graft rejection, common clinical manifestations in VL patients, VL diagnosis methods, drugs used for VL treatment, and response to therapeutics. Laboratory data included hematocrit, platelets, leukocytes, serum albumin, creatinine and urea. All laboratory tests were performed at the beginning (day 1), middle (day 5), and end (day 10) of VL treatment as well as 90 and 180 days post-VL treatment in cured patients. Response to therapeutics was classified as disease progression to complete remission, death, graft dysfunction or return to dialysis.

\section{Data collection}

After approval from the hospitals' respective ethics committees, data were collected through patient interviews and a structured questionnaire explained and proctored by the researchers. Detailed questions included demographics, routines and socioeconomic conditions. Interviews were performed in a private room at the ambulatory care unit and lasted about 30 minutes. If one or more family members were present, they were also allowed to participate in the interview. In cases of deceased patients, interviews were performed with the spouse or a direct family member during domestic visits. Recording procedures for clinical and laboratory variables, clinical evaluation, and VL treatment were reviewed and a new assessment of patients and grafts was performed at 6 months post-treatment.

\section{Statistical analysis}

Statistical analyses were performed with the use of descriptive statistics including means, standard deviations, frequencies and percentages. To determine if data were distributed normally, tests of equal proportions among all variables (general, epidemiologic and clinical aspects as well as responses to therapy [21]) were performed using the $\chi^{2}$ test.

Friedman ANOVA was used to analyze laboratory data, because the normality of the data could not be validated. When a significant difference was found by Friedman ANOVA, the Wilcoxon test was used as a post hoc test for multiple comparisons to test the pairs of variables that differed significantly. In such cases, significance was tested after performing a Bonferroni correction in which $p$-values $<0.05$ were divided by the number of comparisons made. The baseline values were compared with values at each time point, which led to an a priori significance of 0.0125 (0.05/4 comparisons) for all variables except albumin, which had an a priori significance of 0.0166 (0.05/3 comparisons). Differences were considered significant only when $p \leq 0.0125$ (or 0.0166 in the case of albumin) by the Wilcoxon test $[22,23]$. The level of significance for all tests performed was $p<0.05$.

\section{Results}

\section{Patient characteristics}

The general characteristics of the patients are shown in Table 1. The proportion of male patients with posttransplant VL was significantly greater than the proportion of female patients $(80 \%$ vs. $20 \%$, respectively; $p=0.001$ ). Patient age ranged between 22 and 60 years with a mean \pm SD of $40.07 \pm 10.50$ years. There was a statistically significant difference with respect to ethnicity $(p=0.002)$, with a low percentage of brownskinned patients (3.3\%). The majority (90\%) of patients were undergoing hemodialysis and had undergone their first transplantation before VL. A total of 56.7\% of transplants were from live donors, the majority of whom were male (66.7\%). Parents accounted for 33.3\% of donors. Diseases leading to chronic renal disease included arterial hypertension in $50 \%$ of cases or diabetes mellitus in $33.3 \%(p=0.002)$.

\section{Epidemiologic characteristics}

The epidemiologic characteristics of the patients are shown in Table 2. There were uniform distributions of areas of residence $(p=1.000)$ and workplace locations $(p=0.099)$. Only one patient had an advanced education (3.3\%) $(p=0.003)$, and only one patient $(3.3 \%)$ had a family income greater than US\$ $601 \quad(p=0.002)$. There were no statistically significant differences with respect to VL $(p=0.200)$ between patients who lived with animals (63.3\%) and those who did not (36.7\%). There were significant differences between patients who lived with dogs, cats, chickens, and birds but not pigs, and those who did not $(p=0.005, p=0.001$, $p=0.016$, and $p=0.005$, respectively). The percentage of VL patients who had plants in or around the house was significantly different from the percentage of $\mathrm{VL}$ patients who did not $(p=0.000$ and $p=0.000$, respectively). Sanitation and hygienic conditions in housing were considered adequate in $90 \%$ of cases. The proportions of patients who were aware of VL disease in humans and the VL vector were not significantly different, whereas significantly more patients were aware of canine leishmaniasis (CL) (86.7\%) compared with those who were not aware $(p=0.000)$. 
Table 1 General characteristics of $\mathbf{3 0}$ renal transplant recipients with post-transplant visceral leishmaniasis

\begin{tabular}{|c|c|c|c|}
\hline Variable & Mean (SD)* & $n(\%)$ & P-value** \\
\hline Age (years) & $40.07(10.5)$ & & - \\
\hline \multicolumn{4}{|l|}{ Sex } \\
\hline Male & & $24(80.0)$ & 0.001 \\
\hline Female & & $6(20.0)$ & \\
\hline \multicolumn{4}{|l|}{ Ethnicity } \\
\hline White & & $13(43.3)$ & 0.002 \\
\hline Black & & $16(53.3)$ & \\
\hline Brown & & $1(3.3)$ & \\
\hline \multicolumn{4}{|l|}{ Kidney transplant } \\
\hline First transplant & & $27(90.0)$ & 0.001 \\
\hline Re-transplant & & $3(10.0)$ & \\
\hline \multicolumn{4}{|l|}{ Donor type } \\
\hline Alive & & $17(56.7)$ & 0.585 \\
\hline Dead & & $13(43.3)$ & \\
\hline \multicolumn{4}{|l|}{ Donor sex (all donors) } \\
\hline Male & & $20(66.7)$ & 0.099 \\
\hline Female & & $10(33.3)$ & \\
\hline \multicolumn{4}{|c|}{ Degree of kinship of live donors } \\
\hline Second degree & & $11(36.7)$ & \\
\hline Parents & & $10(33.3)$ & 0.043 \\
\hline Siblings & & $8(26.7)$ & \\
\hline Not related & & $1(3.3)$ & \\
\hline \multicolumn{4}{|l|}{ Disease causing CRD } \\
\hline Diabetes mellitus & & $8(26.7)$ & 0.432 \\
\hline Arterial hypertension & & $3(10.0)$ & \\
\hline Unknown & & $5(16.7)$ & \\
\hline Chronic GN & & $5(16.7)$ & \\
\hline Other & & $9(30.0)$ & \\
\hline \multicolumn{4}{|l|}{ Dialysis before transplant } \\
\hline Hemodialysis & & $27(90.0)$ & 0.001 \\
\hline Peritoneal dialysis & & $3(10.0)$ & \\
\hline
\end{tabular}

CRD, chronic renal disease; GN, glomerular nephritis.

* Mean (SD), Mean (Standard Deviation).

${ }^{* *} X^{2}$ test.

Categorical variables are reported as $\mathrm{n}(\%)$.

\section{Clinical characteristics}

The clinical data of patients with post-transplantation $\mathrm{VL}$ are shown in Table 3. The mean number of blood transfusions before transplantation was $0.80 \pm 0.66$ and the mean time between transplantation and VL was $21.3 \pm 16.14$ months with a median of 28 months. The mean number of acute rejections was $0.93 \pm 0.74$. There was a significant difference between at least one blood serotype, with the proportion of serotype B (10\%) apparently causing this difference. The majority of patients were $\mathrm{Rh}$ factor positive $(73.3 \%$; $p=0.001)$. The majority of renal transplant recipients with VL had less than three incompatibility mismatches with the donor (83.3\%), whereas only $16.7 \%$ had a greater number of mismatches $(p=0.001)$. There was no significant difference between the percentages of patients who did and did not receive blood transfusions before transplantation $(43.3 \%$ vs. $56.7 \%$, respectively; $p=0.465$ ). Regarding the use of immunosuppressors, prednisone was used in 100\% of cases, whereas there were significant differences with respect to mycophenolate mofetil and azathioprine use $(p=0.001$ and $p=0.001$, respectively). In contrast, there were no significant differences in the percentages of patients using of tacrolimus or cyclosporine $(p=0.465$ and $p=0.144$, respectively). Significantly more patients underwent induction with monoclonal antibodies than those who underwent no induction (70\% vs. $30 \%$ respectively; $p=0.028$ ). There were no significant differences between the percentages of patients with and without acute rejection ( $40 \%$ vs. $60 \%$ respectively; $p=0.362$ ). All cases studied were first-time VL patients. Regarding post-transplantation infections, cytomegalovirus infection occurred in $40 \%$ of patients $(p=0.362)$ and bacterial infections occurred in $36.6 \%$ of patients $(p=0.002)$.

\section{Symptoms and signs}

The symptoms and signs detected in renal transplant recipients with post-transplantation VL are shown in Table 4. The percentages of patients differed significantly among each of the categories of symptoms and signs $(p<0.05)$, except for the existence of cavity fluids and edema. Even though $67.7 \%$ of patients had these signs, the difference was not statistically significant $(p=0.099)$.

\section{Diagnosis}

VL diagnosis was performed in $100 \%$ of patients (Table 5). Leishmania was directly isolated in $73.3 \%$ of cases, and indirectly detected (immunological test) in $26.7 \%$ of cases $(p=0.016)$. In addition, there were significant differences in the percentages of patients with respect to diagnostic method: myelogram $(p=0.011)$, antigen rK39 isolation $(p=0.000)$, polymerase chain reaction (PCR) $(p=0.000)$, and spleen biopsy $(p=0.000)$. Significantly more patients were treated with liposomal amphotericin (93.3\%) than amphotericin B (6.7\%; $p=0.000$ ). In addition, most patients did not receive $N$ methylglucamine $(23.3 \%$ vs. $76.7 \%$, respectively; $p=0.005)$. After treatment, $26.7 \%$ of patients experienced VL relapse $(p=0.016)$. Furthermore, there were significant differences in the percentages of patients with respect to full cure $(p=0.001)$, death $(p=0.000)$, and achievement of cure with graft dysfunction $(p=0.016)$. No significant differences were observed for cure with graft loss $(p=0.099)$ or cure with return to dialysis $(p=0.099)$. 
Table 2 Epidemiologic characteristics of 30 renal transplant recipients with post-transplantation visceral leishmaniasis

\begin{tabular}{|c|c|c|}
\hline Variable & $n(\%)$ & $P$-value \\
\hline \multicolumn{3}{|l|}{ Residency } \\
\hline Rural area & $15(50.0)$ & 1.000 \\
\hline Urban area & $15(50.0)$ & \\
\hline \multicolumn{3}{|l|}{ Workplace } \\
\hline Urban area & $20(66.7)$ & 0.099 \\
\hline Rural area & $10(33.3)$ & \\
\hline \multicolumn{3}{|l|}{ Transplantation center } \\
\hline Ceará (HGF, HUWC, Barbalha) & $21(70.0)$ & 0.043 \\
\hline Piauí (Casamater) & $9(30.0)$ & \\
\hline \multicolumn{3}{|l|}{ Education level } \\
\hline Basic & $14(46.7)$ & 0.003 \\
\hline Intermediate & $15(50.0)$ & \\
\hline Advanced & $1(3.3)$ & \\
\hline \multicolumn{3}{|l|}{ Cohabitation with domestic animals } \\
\hline Yes & $19(63.3)$ & 0.200 \\
\hline No & $11(36.7)$ & \\
\hline \multicolumn{3}{|l|}{ Cohabitation with dogs } \\
\hline Yes & $23(76.7)$ & 0.005 \\
\hline No & $7(23.3)$ & \\
\hline \multicolumn{3}{|l|}{ Cohabitation with cats } \\
\hline Yes & $24(80.0)$ & 0.001 \\
\hline No & $6(20.0)$ & \\
\hline \multicolumn{3}{|l|}{ Cohabitation with chickens } \\
\hline Yes & $22(73.3)$ & 0.016 \\
\hline No & $8(26.7)$ & \\
\hline \multicolumn{3}{|l|}{ Cohabitation with birds } \\
\hline Yes & $23(76.7)$ & 0.005 \\
\hline No & $7(23.3)$ & \\
\hline \multicolumn{3}{|l|}{ Cohabitation with pigs } \\
\hline Yes & $11(37.9)$ & 0.265 \\
\hline No & $19(63.3)$ & \\
\hline \multicolumn{3}{|l|}{ Plant breeding at home } \\
\hline Yes & $27(90.0)$ & 0.000 \\
\hline No & $3(10.0)$ & \\
\hline \multicolumn{3}{|l|}{ Plant breeding in surroundings } \\
\hline Yes & $27(90.0)$ & 0.000 \\
\hline No & $3(10.0)$ & \\
\hline \multicolumn{3}{|l|}{ Awareness of human VL } \\
\hline Yes & $11(37.9)$ & \\
\hline No & $19(63.3)$ & 0.200 \\
\hline \multicolumn{3}{|l|}{ Awareness of $\mathrm{VL}$ vector } \\
\hline Yes & $10(33.3)$ & \\
\hline
\end{tabular}

Table 2 Epidemiologic characteristics of $\mathbf{3 0}$ renal transplant recipients with post-transplantation visceral leishmaniasis (Continued)

\begin{tabular}{lll}
\hline No & $20(66.7)$ & 0.099 \\
Awareness of CL & & \\
$\quad$ Yes & $4(13.3)$ & \\
No & $26(86.7)$ & 0.000 \\
Family income nonthly & & \\
Low (<US\$ 200) & $15(50.0)$ & 0.003 \\
Average (between US\$ 201 and 600) & $14(46.7)$ & \\
High (>US\$ 600) & $1(3.3)$ & \\
\hline
\end{tabular}

HGF, Hospital Geral de Fortaleza; HUWC, Hospital Universitário Walter Cantídio; $\mathrm{VL}$, visceral leishmaniasis; $\mathrm{CL}$, canine leishmaniasis. ${ }^{*} \chi^{2}$ test. Categorical variables are reported as $\mathrm{n}(\%)$.

\section{Laboratory data}

Laboratory data were analyzed for all patients $(n=30)$ at the initiation of the study (day 0 ) and at days 5 and 10 of treatment (Table 6). Additionally, the same examinations were performed 90 days and 180 days post-VL treatment for all cured cases $(n=24)$. Friedman ANOVA was performed to evaluate possible differences among the results of the hematological and biochemical parameters at different time points during VL treatment. Except for urea, which remained unchanged during treatment $(p=0.511)$, there were significant differences among all other parameters at different time points. Multiple pairwise comparisons between the baseline and subsequent time points by the Wilcoxon test with Bonferroni correction showed only creatinine increased significantly between baseline and day $5(p=0.007)$. Hematocrit differed significantly between baseline and day $10(p=0.000)$, day $90(p=0.000)$, and day $180(p=0.000)$, with an increase in red blood cells from day 10. Leukocytes and platelets also differed significantly between baseline and days 5, 10, 90, and 180. Even though albumin was significantly different by Friedman ANOVA, pairwise multiple comparisons between albumin levels at baseline and days 5, 90, and 180 did not reveal significant differences. This indicated albumin remained unchanged from the beginning of treatment until the time points studied $(p=0.962 ; p=0.588$, and $p=0.182$, respectively).

\section{Discussion}

Fewer than 100 cases of renal transplant recipients with VL have been reported [24,25]. This study investigated the largest number of VL-cases in renal transplant recipients to date. We hope this study of the epidemiologic, clinical, and diagnosis characteristics of VL will become a reference for transplantation teams to adequately follow-up renal transplant recipients with VL, as well as direct treatments, thus, reducing patient mortality and 
Table 3 Clinical characteristics of $\mathbf{3 0}$ renal transplant recipients with post-transplantation visceral leishmaniasis

\begin{tabular}{|c|c|c|c|}
\hline Variable & Mean (SD)* & $n(\%)$ & $P$-value* \\
\hline $\begin{array}{l}\text { Number of blood transfusions } \\
\text { before RTx }\end{array}$ & $0.80(0.66)$ & - & - \\
\hline $\begin{array}{l}\text { Median time between RTx and } \\
\text { VL (months) }\end{array}$ & 28 & - & - \\
\hline $\begin{array}{l}\text { Mean time between RTx and } \\
\text { VL (months) }\end{array}$ & $21.3(16.15)$ & - & - \\
\hline Acute rejection episode & $0.93(0.74)$ & - & - \\
\hline \multicolumn{4}{|l|}{ Blood transfusion before RTx } \\
\hline Yes & & $13(43.3)$ & 0.465 \\
\hline No & & $17(56.7)$ & \\
\hline \multicolumn{4}{|l|}{ Blood type of recipient } \\
\hline Serotype $O$ & & $14(46.7)$ & 0.025 \\
\hline Serotype A & & $13(43.3)$ & \\
\hline Serotype B & & $3(10.0)$ & \\
\hline \multicolumn{4}{|l|}{$\mathrm{Rh}^{\infty}$ factor of recipient } \\
\hline Positive & & $22(73.3)$ & 0.011 \\
\hline Negative & & $8(26.7)$ & \\
\hline \multicolumn{4}{|l|}{$\begin{array}{l}\text { Incompatible mismatches, } \\
\text { recipient-donor }\end{array}$} \\
\hline$\leq 3$ mismatches & & $25(83.3)$ & 0.001 \\
\hline$>3$ mismatches & & $5(16.7)$ & \\
\hline \multicolumn{4}{|l|}{ Use of prednisone } \\
\hline Yes & & $30(100.0)$ & - \\
\hline No & & $0(0.0)$ & \\
\hline \multicolumn{4}{|l|}{ Use of azathioprine } \\
\hline Yes & & $6(20.0)$ & 0.001 \\
\hline No & & $22(80.0)$ & \\
\hline \multicolumn{4}{|l|}{ Use of cyclosporine } \\
\hline Yes & & $11(36.7)$ & 0.200 \\
\hline No & & $19(63.3)$ & \\
\hline \multicolumn{4}{|l|}{ Use of tacrolimus } \\
\hline Yes & & $17(56.7)$ & 0.565 \\
\hline No & & $13(43.3)$ & \\
\hline \multicolumn{4}{|l|}{ Use of $\mathrm{MMF}^{\#}$} \\
\hline Yes & & $27(90.0)$ & 0.000 \\
\hline No & & $3(10.0)$ & \\
\hline \multicolumn{4}{|l|}{$\begin{array}{l}\text { Induction with monoclonal } \\
\text { antibody }\end{array}$} \\
\hline Yes & & $21(70.0)$ & 0.043 \\
\hline No & & $9(30.0)$ & \\
\hline \multicolumn{4}{|l|}{$\begin{array}{l}\text { Acute rejection } \\
\text { post-transplantation }\end{array}$} \\
\hline Yes & & $12(40.0)$ & 0.362 \\
\hline No & & $18(60.0)$ & \\
\hline
\end{tabular}

Table 3 Clinical characteristics of $\mathbf{3 0}$ renal transplant recipients with post-transplantation visceral leishmaniasis (Continued)

\begin{tabular}{lll}
\hline Patients with VL before RTx & & \\
Yes & $0 .(0.0)$ & \\
No & $30(100.0)$ & - \\
$\mathrm{CMV}^{\neq}$infection & & \\
post-transplantation & & \\
Yes & $12(40.0)$ & 0.362 \\
No & $18(60.0)$ & \\
Bacterial infection & & \\
post-transplantation & & \\
Yes & $11(36.6)$ & 0.002 \\
No & $19(73.4)$ & \\
Recipient with positive & & \\
serology for other viruses & & \\
No & $20(66.7)$ & 0.068 \\
Yes & $10(27.0)$ & \\
\hline
\end{tabular}

$R T x$ renal transplantation, $V L$ visceral leishmaniasis, $R h$ Rhesus factor MMF mycophenolate mofetil, CMV cytomegalovirus, *Mean (SD)*, Mean (SD), Mean (Standard Deviation).

${ }^{* *} X^{2}$ test. Categorical variables are reported as $\mathrm{n}(\%)$.

improving the preservation of graft function [11]. In this series, $80 \%$ of patients were men, who were more likely to be exposed to the mosquito vector of VL (Lutzomyia longipalpis) as a result of professional activities, greater body surface area, and the habit of remaining shirtless in the high-temperature environments characteristic of tropical regions [26,27]. Despite the lack of reports of an association between ethnicity and VL, the majority of patients in the present study were black. Only one previous study addressed the issue of the period between transplantation and VL diagnosis; however, there are no reports of an association between $\mathrm{VL}$ and the type or dose of immunosuppressors used. A recent case-control study of multivariate analysis of renal transplant recipients that coexisted with cats with or without VL, showed bacterial infections after transplant and inadequate socioeconomic conditions increased the risk for disease [11]. Other studies showed the mosquito vector had migrated from rural to urban areas [28,29]. The majority of studies in the literature report dogs are the main intermediary host in the life cycle of VL. However, cats are also important hosts of Leishmania [11]. VL is a neglected disease that is highly prevalent in the world's poorest regions and is positively correlated with deficient hygiene and sanitation [30,31]. However, the present study shows that the majority of VL patients had access to purified water, electricity and regular waste collection. This suggests immunosuppression might be a determinant cause of VL in these patients, related to the use of immunosuppressors, hemodialysis, post-transplant 
Table 4 Clinical manifestations in $\mathbf{3 0}$ renal transplant recipients with post-transplantation visceral leishmaniasis

\begin{tabular}{lll}
\hline Variable & $\boldsymbol{n}(\%)$ & $\boldsymbol{P}_{\text {-value }}^{*}$ \\
\hline Fever & & \\
Yes & $21(70.0)$ & 0.043 \\
No & $9(30.0)$ &
\end{tabular}

Weight loss

$\begin{array}{ll}\text { Yes } & 30(100.0)- \\ \text { No } & 0(0.0)\end{array}$

Skin lesions

$\begin{array}{lll}\text { Yes } & 25(83.3) & 0.000 \\ \text { No } & 5(16.7) & \\ \text { Splenomegaly } & & \\ \text { Yes } & 28(93.3) & 0.000 \\ \text { No } & 2(6.7) & \end{array}$

Hepatomegaly

Yes

No

$21(70.0) \quad 0.043$

$9(30.0)$

Active bleeding of the digestive tract mucosae

$\begin{array}{lll}\text { Yes } & 7(23.3) & 0.005 \\ \text { No } & 23(66.7) & \\ \text { Jaundice } & & \\ \text { Yes } & 6(20.0) & 0.001 \\ \text { No } & 22(80.0) & \end{array}$

Pale skin and mucosae

$\begin{array}{lll}\text { Yes } & 21(70.0) & 0.043 \\ \text { No } & 9(30.0) & \end{array}$

Weakness and myalgia

Yes

$23(76.7) \quad 0.005$

No

Diarrhea

Yes

No

Fluids in visceral cavities

\begin{tabular}{lll} 
Yes & $20(66.7)$ & \\
No & $10(33.3)$ & 0.099 \\
\hline
\end{tabular}

${ }^{*} X^{2}$ test.

Categorical variables are reported as $\mathrm{n}(\%)$.

infection, malnutrition and donor incompatibility, especially in cases of deceased donors [11,32,33]. Several studies failed to demonstrate a relationship between blood serotype and VL. The present study observed significant differences in the percentages of patients with respect to blood type and $\mathrm{Rh}$ factor, although there was no clinical explanation for this $[34,35]$.

Previous studies reported difficulties in diagnosing VL in renal transplant recipients because of atypical signs
Table 5 Diagnosis, treatment, and response to therapeutics in $\mathbf{3 0}$ renal transplant recipients with post-transplantation visceral leishmaniasis

\begin{tabular}{|c|c|c|}
\hline Variable & $n(\%)$ & $P$-value* \\
\hline \multicolumn{3}{|l|}{ VL diagnosis } \\
\hline Direct identification of the parasite & $22(73.3)$ & 0.016 \\
\hline Indirect method (immunological) & $8(26.7)$ & \\
\hline \multicolumn{3}{|l|}{ Myelogram } \\
\hline Yes & $19(63.3)$ & 0.011 \\
\hline No & $11(26.7)$ & \\
\hline \multicolumn{3}{|l|}{ Antigen rk39 isolation } \\
\hline Yes & $5(16.7)$ & 0.000 \\
\hline No & $25(83.3)$ & \\
\hline \multicolumn{3}{|l|}{ PCR } \\
\hline Yes & $1(3.3)$ & 0.000 \\
\hline No & $29(96.7)$ & \\
\hline \multicolumn{3}{|l|}{ Spleen biopsy } \\
\hline Yes & $2(6.7)$ & 0.000 \\
\hline No & $28(23.3)$ & \\
\hline \multicolumn{3}{|l|}{ Use of amphotericin } \\
\hline Liposomal amphotericin B & $28(93.3)$ & 0.000 \\
\hline Amphotericin B & $2(6.7)$ & \\
\hline \multicolumn{3}{|l|}{ Use of $\mathrm{N}$-methylglucamine } \\
\hline Yes & $7(23.3)$ & 0.005 \\
\hline No & $21(66.7)$ & \\
\hline \multicolumn{3}{|l|}{ VL relapse } \\
\hline Yes & $8(26.7)$ & 0.016 \\
\hline No & $22(73.3)$ & \\
\hline \multicolumn{3}{|l|}{ Patients with VL remission } \\
\hline Yes & $24(80.0)$ & 0.001 \\
\hline No & $6(20.0)$ & \\
\hline \multicolumn{3}{|l|}{ Deceased patients } \\
\hline Yes & $5(16.7)$ & 0.000 \\
\hline No & $25(83.3)$ & \\
\hline
\end{tabular}

Patients with VL remission and graft loss

$\begin{array}{lll}\text { Yes } & 10(33.3) & 0.099 \\ \text { No } & 20(66.7) & \end{array}$

Patients with VL remission and graft dysfunction

$\begin{array}{lll}\text { Yes } & 22(73.3) & 0.016\end{array}$

No 8 (26.7)

Patients with VL remission and return to dialysis

Yes

$10(33.3) \quad 0.099$

No

$20(66.7)$

$V L$ visceral leishmaniasis, $r K 39$ antigen extracted from Leishmania sp., $P C R$ polymerase chain reaction.

${ }^{*} X^{2}$ test.

Categorical variables are reported as $\mathrm{n}(\%)$. 
Table 6 Laboratory data of post-transplant visceral leishmaniasis patients in remission and up to 6 months post-transplantation

\begin{tabular}{|c|c|c|}
\hline Variable & Mean (SD)* & $P$-value ${ }^{* *}$ \\
\hline Creatinine $(\mathrm{mg} / \mathrm{dL})$ & & 0.002 \\
\hline $1^{\text {st }}$ evaluation & $1.81(0.4)$ & \\
\hline $2^{\text {nd }}$ evaluation & $2.21(0.46)$ & \\
\hline $3^{\text {rd }}$ evaluation & $1.9(1.17)$ & \\
\hline 90 days post-treatment & $1.77(0.27)$ & \\
\hline 180 days post-treatment & $1.80(0.33)$ & \\
\hline Urea (mg/dL) & & 0.000 \\
\hline $1^{\text {st }}$ evaluation & $105.13(16.91)$ & \\
\hline $2^{\text {nd }}$ evaluation & $97.80(15.89)$ & \\
\hline $3^{\text {rd }}$ evaluation & $65.13(27.18)$ & \\
\hline 90 days post-treatment & $63.40(20.40)$ & \\
\hline 180 days post-treatment & $52.07(9.98)$ & \\
\hline Hematocrit (\%) & & 0.000 \\
\hline $1^{\text {st }}$ evaluation & $28.72(4.18)$ & \\
\hline $2^{\text {nd }}$ evaluation & $29.72(3.65)$ & \\
\hline $3^{\text {rd }}$ evaluation & $34.94(3.50)$ & \\
\hline 90 days post-treatment & $37.73(2.57)$ & \\
\hline 180 days post-treatment & $38.76(1.72)$ & \\
\hline Leukocytes $\left(\mathrm{mm}^{3} / \mathrm{dL}\right)$ & & 0.000 \\
\hline $1^{\text {st }}$ evaluation & $3.07(1.05)$ & \\
\hline $2^{\text {nd }}$ evaluation & $4.51(3.27)$ & \\
\hline $3^{\text {rd }}$ evaluation & $5.86(2.71)$ & \\
\hline 90 days post-treatment & $6.18(1.41)$ & \\
\hline 180 days post-treatment & $6.40(0.95)$ & \\
\hline Platelets $\left(\mathrm{mm}^{3} / \mathrm{dL}\right)$ & & 0.000 \\
\hline $1^{\text {st }}$ evaluation & $110.33(88.18)$ & \\
\hline $2^{\text {nd }}$ evaluation & $178.07(183.17)$ & \\
\hline $3^{\text {rd }}$ evaluation & $163.00(72.02)$ & \\
\hline 90 days post-treatment & $177.00(18.13)$ & \\
\hline 180 days post-treatment & $183.07(11.88)$ & \\
\hline Serum albumin $(\mathrm{mg} / \mathrm{dL})^{+}$ & & 0.009 \\
\hline $1^{\text {st }}$ evaluation & $3.32(0.76)$ & \\
\hline $2^{\text {nd }}$ evaluation & $3.74(0.37)$ & \\
\hline 90 days post-treatment & $3.87(0.34)$ & \\
\hline 180 days post-treatment & $3.99(0.27)$ & \\
\hline
\end{tabular}

$n=24$ remission patients.

$1^{\text {st }}$ evaluation: day 1 of treatment with amphotericin or glucamine.

$2^{\text {nd }}$ evaluation: day 5 of treatment with amphotericin or day 10

with glucamine.

$3^{\text {rd }}$ evaluation: day 10 of treatment with amphotericin or day 20 with glucamine.

${ }^{\dagger}$ Serum albumin was not measured at intermediate time points. *Mean and SD* (Mean (Standard Deviation) of leukocytes and platelets were divided by 1.000 .

Categorical variables are reported as $\mathrm{n}(\%)$.

**Determined by Friedman ANOVA, the Wilcoxon test or ANOVA factor repetition measurements. and symptoms [36,37]. In the present study, clinical manifestations were typical, even in immunosuppressed patients, and disease occurred at a mean \pm SD of $21.6 \pm 16.15$ months (range: 6-110 months) after transplantation with a median of 28 months. This contributed to the differential diagnosis of VL in cases of fever, a characteristic manifestation in all regions including non-endemic regions [38]. VL diagnosis was performed in $100 \%$ of cases, and myelogram was the main method used to identify Leishmania forms. In cases with negative results, indirect determination was performed by the identification of the rK39 antigen. Rapid diagnostic tests (RDTs) may improve the early detection of VL. Therefore, we evaluated the performance of a rK39-based RDT (Kalazar Detect ${ }^{\mathrm{T} w}$ ) for the detection of VL in an endemic, large urban area. Estimates for sensitivity and specificity were $72.4 \%$ and 99.6\%, respectively [39]. Polymerase chain reaction using primers that amplify the conserved region of minicircle kDNA (DNA kinetoplast) is the most effective test for the diagnosis of $\mathrm{LV}$, is minimally invasive as it uses blood samples from patients, and is superior to serology to detect cases of infection [7].

In the present study, liposomal amphotericin was the drug of choice for VL treatment, resulting in high levels of disease remission, low relapse and minimal numbers of deaths [39]. There is no consensus in the literature as to the amphotericin dose for the treatment of VL in renal transplant recipients. Previous studies used lower doses (20 mg divided in four doses and $1 \mathrm{mg} / \mathrm{kg} /$ day for 10 days) and shorter periods of time and observed a high cure rate of VL patients [40,41]. This study investigated cases of VL after renal transplantation diagnosed between 1989 and 2013. Cases with relapse (27,6\%) were treated with $\mathrm{N}$-methyl glucamine. The use of $\mathrm{N}$-methyl glucamine was used in the first 7 cases of VL in kidney transplant because liposomal amphotericin was not used to treat VL $[42,43]$. Anti-leishmaniasis drugs are effective in treating disease but can cause significant side effects. Amphotericin B causes anaphylaxis, anemia, thrombocytopenia, nausea, vomiting, liver and renal failure, cardiac arrest and bronchospasm. Pentavalent antimony causes muscle and joint pain, diffuse abdominal pain, dyspnea, hepatic insufficiency, renal, pancreatic and electrocardiographic alterations $[44,45]$.

The results of the current study showed an association between VL and post-transplantation bacterial and cytomegalovirus infections, which are explained by the reduced immunity of patients, who became more susceptible to opportunistic infectious organisms such as Leishmania [46]. As for immunosuppression, we found no significant difference among renal transplant recipients receiving cyclosporine or FK-506. These drugs have different chemical structures but similar mechanisms of 
action, blocking interleukins and activation of $\mathrm{T}$ and $\mathrm{B}$ lymphocytes, thus reducing patient immune responses [47,48].

Regarding laboratory analyses, the present study indicated that during systemic disease, VL seriously damages the kidneys, liver, spleen and hematopoietic system. Therefore, the early diagnosis and adequate treatment is critical for the significant improvement in patients.

\section{Conclusions}

This study is the largest series of VL in renal transplant recipients, which focused on several aspects of the disease, including epidemiology, clinical profile, diagnosis, and treatment. The results advance our knowledge regarding VL in renal transplant recipients and may increase awareness of this emerging infection among transplantation teams. Standardized routines for the adequate follow-up of VL patients are recommended, taking into consideration the specificity of renal transplant recipients.

\section{Competing interests}

The authors declare that they have no competing interests.

This study received no outside financial support and was performed with the support of the Kidney Transplant Units of the Federal University of São Paulo, Federal University of Ceará, General Hospital of Fortaleza and Federal University of Piauí after approval from the ethics committees of each institution.

\section{Authors' contributions}

AAS, APSF and RCCS participated in the research design, its critical appraisal and aided in data analysis; CMCO, RAO and RME participated in performing the research; PFCBCF, LSVS and VPC participated in performing the research and analyzing data; CHNC contributed to the design and review of the study; DMBS and RVC contributed to the collection of data; and JXA contributed to data analysis. All authors read and approved the final manuscript.

\section{Author details}

${ }^{1}$ General Clinic Department, Federal University of Piauí, Piauí, Brazil. ${ }^{2}$ Renal Transplant Unit, Hospital Alianca Casamater, Piauí, Brazil. ${ }^{3}$ Discipline of Nephrology, Federal University of São Paulo, São Paulo, Brazil. ${ }^{4}$ Renal Transplant Unit, Hospital Israelita Albert Einstein, Sao Paulo, Brazil. ${ }^{5}$ Renal Transplant Unit of the General Hospital of Fortaleza, Ceará, Brazil. ${ }^{6}$ Cantídio Walter University Hospital, Renal Transplant Unit, University Federal do Ceará, Ceará, Brazil. 'Division of Nephrology, Renal Transplant Service, Dr. Joaquim Bezerra Unit, School of Medicine, University of Crato, Ceará, Brazil. ${ }^{8}$ Infectious Diseases Hospital Dr. Natan Portela, Federal University of Piauí, Piauí, Brazil. ${ }^{9}$ Department of Accounting and Administration, Federal University of Piauí, Piauí, Brazil.

Received: 18 June 2014 Accepted: 19 February 2015 Published online: 25 February 2015

\section{References}

1. Palatnik-de-Sousa CB, Day MJ. One health: the global challenge of epidemic and endemic leishmaniasis. Parasit Vector. 2011;4:197.

2. Badaró R, Duarte MIS. Leishmaniose visceral (Calazar). In: Veronesi R, Focaccia R, editors. Tratado de Infectologia. 3ath ed. São Paulo: Ed. Atheneu; 2005. p. 1561-90.

3. Campillo MC, Vazquez FAR, Fernandez ARM. Parasitologia Veterinária (1a ed). Madrid: McGraw-Hill Interamericana; 1999. p. 651-65.

4. Brazil Ministério da Saúde, Secretaria de vigilância em Saúde. Leishmaniose visceral. In: Guia de vigilância epidemiológica/Ministério da Saúde, Secretaria de Vigilância em Saúde. 6th ed. Brasilia: Série A. Normas e Manuais Técnicos; 2005. p. 467.
5. Bouchejoua M, Trabeisi S, Bem Abdallah T, Khaled S. Visceral leishmaniasis after kidney transplantation: report of a new case and a review of the literature. Transplant Rev. 2014;28:32-5.

6. Medina-Pestana JO, Galante NZ, Tedesco-Silva Jr H, Harada KM, Garcia VD, Abbud-Filho M, et al. Kidney transplantation in Brazil and its geographic disparity. J Bras Nefrol. 2011;33:472-84.

7. Lages RC, De Castro JAF, Do Monte SJH, Neto JTM, Andrade HM. Visceral leishmaniasis in kidney transplantation recipients: case report and proposal of early diagnosis of infection in endemic area. J Bras Nefrol. 2004;26:51-6.

8. Cavalcante LJ, Vale MR. Epidemiological aspects of visceral leishmaniasis (kala-azar) in Ceará in the period 2007 to 2011. Ver Bras Epidemiol. 2014;17:911-24.

9. Laupacis A, Keown P, Pus N, Krueger H, Ferguson B, Wong C, et al. A study of the quality of life and cost-utility of renal transplantation. Kidney Int 1996;50:235-42.

10. Oliveira CM, Oliveira ML, Andrade SC, Girão ES, Ponte CN, Mota MU, et al. Visceral leishmaniasis in renal transplant recipients: clinical aspects, diagnostic problems, and response to treatment. Transplant Proc. 2008:40:755-60

11. Oliveira RA, Silva LS, Carvalho VP, Coutinho AF, Pinheiro FG, Lima CG, et al Visceral Leishmaniasis after renal transplantation: report of 4 cases in northeastern Brazil. Transpl Infect Dis. 2008;10:364-8.

12. Alves da Silva A, Pacheco-Silva A, De Castro Cintra Sesso R, Esmeraldo RM, Costa de Oliveira CM, Fernandes PF, et al. The risk factors for and effects of visceral leishmaniasis in graft and renal transplant recipients. Transplantation. 2013:95:721-7

13. Camargo JB, Troncarelli MZ, Ribeiro MG, Langoni H. Leishmaniose visceral canina: aspectos de saúde pública e controle. Clín Vet. 2007;71:86-92.

14. Siqueira FV, Nahas MV, Facchini LA. Factors considered important for health maintenance by the population. Rev Saude Publica. 2009:43:961.

15. Caravaca F, Muñoz A, Pizarro JL, Saez de Santamaría J, Fernandez-Alonso J. Acute renal failure in visceral leishmaniasis. Am J Nephrol. 1991;11:350-2.

16. Escobar P, Matu S, Marques C, Croft SL. Sensitivities of Leishmania species to hexadecylphosphocholine (miltefosine), ET-18-OCH(3) (edelfosine) and amphotericin B. Acta Trop. 2002;81:151-7.

17. Sundar S, Sinha PK, Rai M, Verma DK, Nawin K, Alam S, et al. Comparison of short-course multidrug treatment with standard therapy for visceral leishmaniasis in India: an open-label, non-inferiority, randomized controlled trial. Lancet. 2011;377:477-86.

18. Kumar N, Sinha PK, Pandey K, Verma N, Lal CS, Ranjan A, et al. A rare case of visceral leishmaniasis with multiple relapse and multi-drug unresponsive: successfully treated with combination therapy. Int J Clin Pharm. 2011:33:726-9.

19. Sandar S, Ray M. Advances in the treatment of leishmaniasis, vol. 15 2002. p. 593-8.

20. Colvin RB, Nickeleit V. Renal transplant pathology. In: Jennette JL, Olson MM, Schwartz FG, editors. Heptinstall's Pathology of the Kidney. 4th ed. Philadelphia: Lippincott-Raven; 2006. p. 1347-90.

21. Field AP. Discovering Statistics Using SPSS. 3rd ed. London: Sage; 2009. p. 227-8.

22. Armitage P, Berry G, Matthews JNS. Statistical Methods in Medical Research. 3rd ed. London (GB): Blackwell Scientific Publications; 2002. p. 136

23. Hosmer DW, Lemeshow S. Applied Logistic Regression. New York: John Wiley \& Sons; Inc; 2000. p. 95

24. Dettwiler S, McKee T, Hadaya K, Chappuis F, Van Delden C, Moll S. Visceral leishmaniasis in a kidney transplant recipient: parasitic interstitial nephritis, a cause of renal dysfunction. Am J Transplant. 2010;10:1486-9.

25. Simon I, Wissing KM, Del Marmol V, Antinori S, Remmelink M, Nilufer

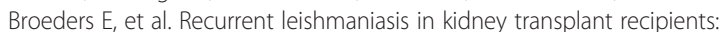
report of 2 cases and systematic review of the literature. Transpl Infect Dis. 2011;13:397-406

26. Ali A, Ashford RW. Visceral Leishmaniasis in Ethiopia. The magnitude and annual incidence of infection, as measured by serology in an endemic area. Ann Trop Med Parasitol. 1994:88:43-7.

27. Deane ML, Deane MP. Visceral Leishmaniasis in Brazil: geographical distribution and transmission. Rev Inst Med Trop Sao Paulo. 1962:4:198-212.

28. Savani ES, de Oliveira Camargo MC, de Carvalho MR, Zampieri RA, dos Santos MG, D'Auria SR, et al. The first record in the Americas of an autochthonous case of Leishmania (Leishmania) infantum chagasi in a domestic cat (Felix catus) from Cotia County, São Paulo State. Vet Parasitol. 2004;120:229-33. 
29. Murray HW, Berman JD, Davies CR, Saravia NG. Advances in leishmaniasis. Lancet. 2005;366:1561-77.

30. Neves J. Diagnosis and treatment of kala-azar. Rev Paul Med. 1983;101:237-9.

31. Lainson R, Dye C, Shaw JJ, Macdonald DW, Courtenay O, Souza AA, et al. Amazonian Visceral Leishmaniasis - Distributions of the vector Lutzomyia longipalpis (Lutz e Neiva) in relation to the Cerdocyon thous (Linn) and the efficiency of this reservoir host as a source of infection. Mem Inst Oswaldo Cruz. 1990;85:135-7.

32. Lopez C. Association of renal allograft rejection with virus infection. Am J Med. 1974:56:280-9.

33. Kaye PM, Aebischer T. Visceral Leishmaniasis: immunology and prospects for a vaccine. Clin Microbiol Infect. 2011;17:1462-70.

34. Machado CM, Levi JE. Transplant-associated and blood transfusion-associated tropical and parasitic infections. Infect Dis North Am. 2012;26:225-41.

35. Guerin PJ, Olliaro P, Sundar S, Boelaert M, Croft SL, Desjeux P, et al. Viscera Leishmaniasis: current status of control, diagnosis and treatment and a proposed research and development agenda. Lancet Infect Dis. 2002;2:494-501.

36. Ikeda-Garcia FA, Lopes RS, Ciarlini PC, Marques FJ, Lima VM, Perri SH, et al. Evaluation of renal and hepatic functions in dogs naturally infected by visceral leishmaniasis submitted to treatment with meglumine antimoniate. Res Ver Sci. 2007;83:105-8.

37. Toumi A, Kilani B, Tiouiri H, Kanoun F, Beihadj S, Chaker E, et al. Demographic, clinical and therapeutic features of adult visceral leishmaniasis at the Rabta hospital in Tunis (Tunisia) from 1983 to 2002. Bull Soc Pathol Exot. 2007;100:282-6.

38. Jha RK, Sah AK, Shah DK, Sah P. The treatment of visceral leishmaniasis: safety and efficacy. J Nepal Med Assoc. 2013;52:645-51.

39. Nath P, Baster A, Harada M, Sarkar S, Selim S, Maude RJ, et al. Immediate hypersensitivity reaction following liposomal amphotericin - B 9AmBisome) infusion. Trop Doct. 2014;44:241-2.

40. Moura AS, Lopes HW, Mourão MV, Morais MH. Performance of a rapid diagnostic test for the detection of visceral leishmaniasis in a large urban setting. Rev Soc Bras Trop. 2013;46:589-93.

41. Lachaud L, Chabbert E, Dubessay P, Reynes J, Lamothe J, Bastien P. Comparison of various sample preparation methods for PCR diagnosis of visceral leishmaniasis using peripheral blood. J Clin Microbiol. 2001;39:613-7.

42. Thakur CP, Kumar A, Mitra DK, Roy A, Sinha AK, Ranjan A. Improving outcome of treatment of kala-azar by supplementation of amphotericin B with physiologic saline and potassium chloride. Am J Trop Med Hyg. 2010;83:1040-3.

43. Meuer SC, Meuer MP. Selective blockade of the antigen-receptor-mediated pathway of T cell activation in patients with impaired primary immune responses. J Clin Invest. 1987;80:743-74.

44. Pourmand G, Salem S, Mehrsai A, Taherimahmoudi M, Ebrahimi R, Pourmand MR. Infectious complications after kidney transplantation: a single-center experience. Transpl Infect Dis. 2007;9:302-9.

45. Burza S, Sinha PK, Mahaian R, Sanz MG, Lima MA, Mitra G, et al. Post Kala-Azar dermal leishmania for primary visceral leishmaniasis in Bihar. India PLoS Negl Trop Dis. 2014;8:e2611.

46. Antinori S, Cascio A, Parravicini C, Bianchi R, Corbellino M. Leishmaniasis among organ transplant recipients. Lancet Infect Dis. 2008:8:191-8.

47. Kaushal H, Bras-Goncalves R, Negi N, Lemesre JL, Papierok G, Salotra P. Role of CD8(+) T cells in protection against Leishmania donovani infection in healed Visceral Leishmaniasis individuals. BMC Infect Dis. 2014;14:653.

48. Meaney CJ, Arabi Z, Venuto RC, Consiglio JD, Wilding GE, Tornatore KM. Validity and reliability adverse effects scoring system in renal transplant recipients. BMC Nephrol. 2014;15:88. Jun 12.

\section{Submit your next manuscript to BioMed Central and take full advantage of:}

- Convenient online submission

- Thorough peer review

- No space constraints or color figure charges

- Immediate publication on acceptance

- Inclusion in PubMed, CAS, Scopus and Google Scholar

- Research which is freely available for redistribution 